\title{
Effect of fixed-appliance orthodontic treatment on DMFT-index
}

\author{
Efka Zabokova-Bilbilova ${ }^{1}$, Emilija Sefanovska ${ }^{2}$, Aneta Mijoska $^{3}$, \\ Olga Kokoceva-Ivanovska ${ }^{1}$
}

\author{
${ }^{1}$ Clinic of Pediatric and Preventive Dentistry, Faculty of Dentistry, \\ Ss. Cyril and Methodius University, Mother Theresa 17, 1000 Skopje, North Macedonia \\ ${ }^{2}$ Clinic of Periodontology and Oral Pathology, Faculty of Dentistry, \\ Ss. Cyril and Methodius University, Mother Theresa 17, 1000 Skopje, North Macedonia \\ ${ }^{3}$ Clinic of Prosthodontics, Faculty of Dentistry, Ss. Cyril and Methodius University, \\ Mother Theresa 17, 1000 Skopje, North Macedonia
}

Received: December 2020; Accepted: February 2021

\begin{abstract}
The aim of the study was to evaluate changes in dental status during fixed orthodontic treatment. A total of 60 patients with diagnosed malocclusion were included. Subjects were divided in 3 groups (20 subjects in each group). The first group was treated with dental cream GC Tooth Mousse, and the second group with Fluorogal - solution with a low concentration of fluoride (0.05\% F). Control group comprised 20 patients. All subjects received precise instructions for oral hygiene and exclusion of dietary intake before fixed orthodontic appliance was placed and during each control. In our study clinical oral health status (DMFT-index) was registered before and at the end of the orthodontic treatment.

The subjects treated with dental cream GC Tooth Mousse at the end of the orthodontic treatment had increased DMFT-index 5.85 in comparison to the beginning of the treatment, where the average value of the index was 5.25 (however, the difference was not statistically significant). A statistically significant difference between medium values of the DMFT-index before and after the orthodontic treatment was detected in the control group.

The results of this study show that DMFT-index increased in a group of dental patients undergoing orthodontic therapy with fixed appliances. The patients must follow good instructions, motivation, and control of oral hygiene during the treatment.
\end{abstract}

Keywords: carious lesions, fixed orthodontic appliance

\section{Introduction}

Dental caries is an infection multifactorial, a microbiological disease that results in localized dissolution and destruction of calcified tissues of the teeth (Roberson, 2006). Orthodontic treatment with fixed appliances based on brackets and arch wires creates numerous plaque retention sites and thus increases a patient's risk of developing caries and inflammatory reactions in gingival tissue. Actually, it needs more than the regular practice of brushing to maintain oral hygiene in orthodontic patients. The majority of patients undergoing orthodontic treatment are adolescents and young adults, which is the generation having a food pattern.

Demineralization of enamel around brackets can be an extremely rapid process and appears most frequently

\footnotetext{
* efka zabokova@hotmail.com
} 
on the cervical and middle thirds of the buccal surfaces of the maxillary lateral incisors, the mandibular canines, and the first premolars (Anas et al., 2009). Demineralized enamel can remineralize after debonding under favorable conditions.

Studies evaluating the relationship between orthodontic treatment and dental caries have shown contradictory results. Some authors (Ali et al., 2011; Sukhia et al., 2006) have reported a positive correlation between orthodontic treatment and the incidence of caries. Others (Amy et al., 2011; Stahl et al., 2004) have even reported a negative relationship between fixed orthodontic appliances and caries.

The aim of the study was to evaluate changes in dental status during fixed orthodontic treatment.

\section{Materials and methods}

A total of 60 patients with diagnosed malocclusion were included. Subjects were divided into 3 groups (20 subjects in each group). The first group was treated with dental cream GC Tooth Mousse, and the second group with Fluorogal - a solution with a low concentration of fluoride $(0.05 \% \mathrm{~F})$. The third group was a control group.

Patients were selected randomly to the Orthodontic Clinic at the University Dental Clinic Center in Skopje. All subjects received precise instructions for oral hygiene and exclusion of dietary intake before fixed orthodontic appliance was placed and during each control. In our study, clinical oral health status was registered before and at the end of the orthodontic treatment. DMFT-index was measured with a mouth mirror and a blunt probe under clinical lighting, prior to and after drying the tooth surface with compressed air according to the World Health
Organization caries diagnostic criteria for epidemiological studies (WHO, 1997).

\section{Results}

Student's t-test for dependent samples in subjects treated with fluoride solution (Fluorogal) showed a statistically significant difference between medium values of the DMFT-index before and after orthodontic treatment. The differences were not statistically significant between the group treated with preventive dental cream (GC Tooth Mousse), and the control group (Table 1).

Table 2. Values of DMFT - index before treatment in group I, II and III

\begin{tabular}{cccc}
\hline Group & $\overline{\mathrm{X}}$ & $S D$ & $N$ \\
\hline I & 5.25 & 2.38 & 20 \\
II & 4.95 & 2.72 & 20 \\
III & 6.45 & 4.12 & 20 \\
\hline
\end{tabular}

The analysis of variance (Tab. 2; Fig. 1) showed no statistically significant difference between the groups in relation to the DMFT-index by the treatment $(F=1.540$; $p=0.229$ ). Tukey's HSD (honestly significant difference) test showed differences (not statistically significant), among medium values in the DMFT-index in the examined groups before the treatment (Table 3).

Table 1. The values of the DMFT - index in subjects of all groups

\begin{tabular}{|c|c|c|c|c|c|}
\hline GROUP & DMFT - INDEX & $\overline{\mathrm{X}}$ & $S D$ & $T$ & $P$ \\
\hline \multirow{2}{*}{ I } & BEFORE TREATMENT & 5.25 & 2.38 & \multirow{2}{*}{-1.449} & \multirow{2}{*}{0.2147} \\
\hline & AFTER TREATMENT & 5.85 & 2.76 & & \\
\hline \multirow{2}{*}{ II } & BEFORE TREATMENT & 4.95 & 2.72 & \multirow{2}{*}{-1.567} & \multirow{2}{*}{0.1339} \\
\hline & AFTER TREATMENT & 5.35 & 3.07 & & \\
\hline \multirow{2}{*}{ III } & BEFORE TREATMENT & 6.45 & 4.12 & \multirow{2}{*}{-4.702} & \multirow{2}{*}{$0.000155^{*}$} \\
\hline & AFTER TREATMENT & 7.50 & 4.41 & & \\
\hline
\end{tabular}

\footnotetext{
*statistically significant differences

I group: brackets bonded with Fuji Ortho ${ }^{\mathrm{TM}} \mathrm{LC}$ and treatment with GC Tooth Mousse

II group: brackets bonded with Fuji Ortho ${ }^{\mathrm{TM}} \mathrm{LC}$ and treatment with Fluorogal

III group: brackets bonded with Fuji Ortho ${ }^{\mathrm{TM}}$ LC (control group)
} 


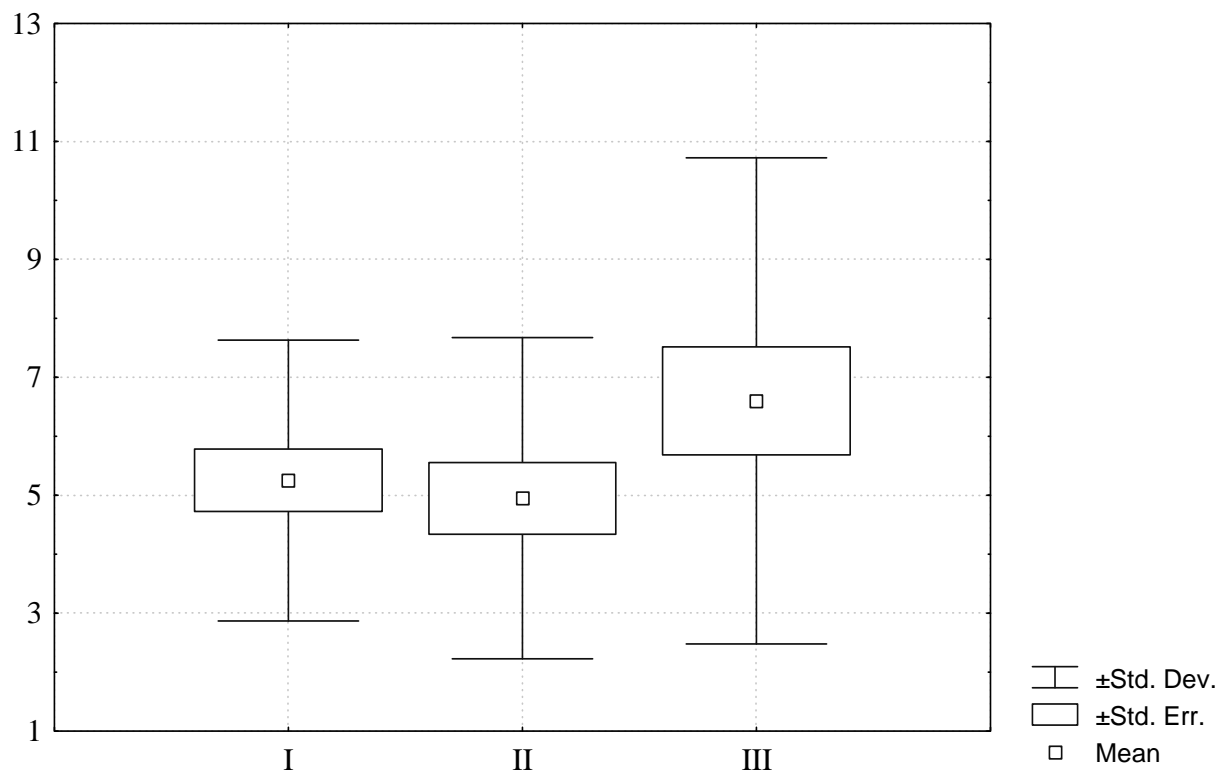

Fig. 1. Values of DMFT - index before treatment in subjects of all groups.

Table 3. Difference between values of DMFT - index before treatment in all groups

\begin{tabular}{cc}
\hline Group & $p$ \\
\hline I and II & 0.9518 \\
I and III & 0.3749 \\
II and III & 0.2343 \\
\hline
\end{tabular}

*Tukey (HSD) test

The analysis of variance (Table 4; Fig. 2) showed no statistically significant difference between the groups in relation to the DMFT-index by the treatment $(F=2.210$, $p=0.1190$ ). Tukey's HSD test showed differences (not statistically significant), among medium values in the DMFT -index in the examined groups after the treatment (Table 5).

Table 4. Values of DMFT - index after treatment in group I, II and III

\begin{tabular}{cccc}
\hline \hline Group & $\overline{\mathrm{X}}$ & $S D$ & $N$ \\
\hline I & 5.85 & 2.76 & 20 \\
II & 5.35 & 3.07 & 20 \\
III & 7.50 & 4.08 & 20 \\
\hline
\end{tabular}

Table 5. Difference between values of DMFT - index after treatment in all groups

\begin{tabular}{cc}
\hline Group & $p$ \\
\hline I and II & 0.8921 \\
I and III & 0.2759 \\
II and III & 0.1202 \\
\hline
\end{tabular}

\section{Discussion}

After removal of the bands and brackets at the end of orthodontic treatment, clinical examinations often identify the presence of lesions, which may range in severity from incipient, non-cavitated to advanced cavitated, carious lesions. Therefore, patients with fixed appliances must follow very rigid oral hygiene protocols to avoid such side effects.

Some authors suggest that orthodontic treatment with a fixed appliance may be compatible with an increased incidence of caries, and thus orthodontic treatment itself has always been criticized (Al Mulla et al., 2009; Mattousch et al., 2007). Poor oral hygiene is one of the main problems routinely faced in the orthodontic treatment. Orthodontic appliance creates an environment that provides potential space for bacterial flora. This condition is clinically seen as white spot lesions and cavitation in the most severe cases. It was concluded that 


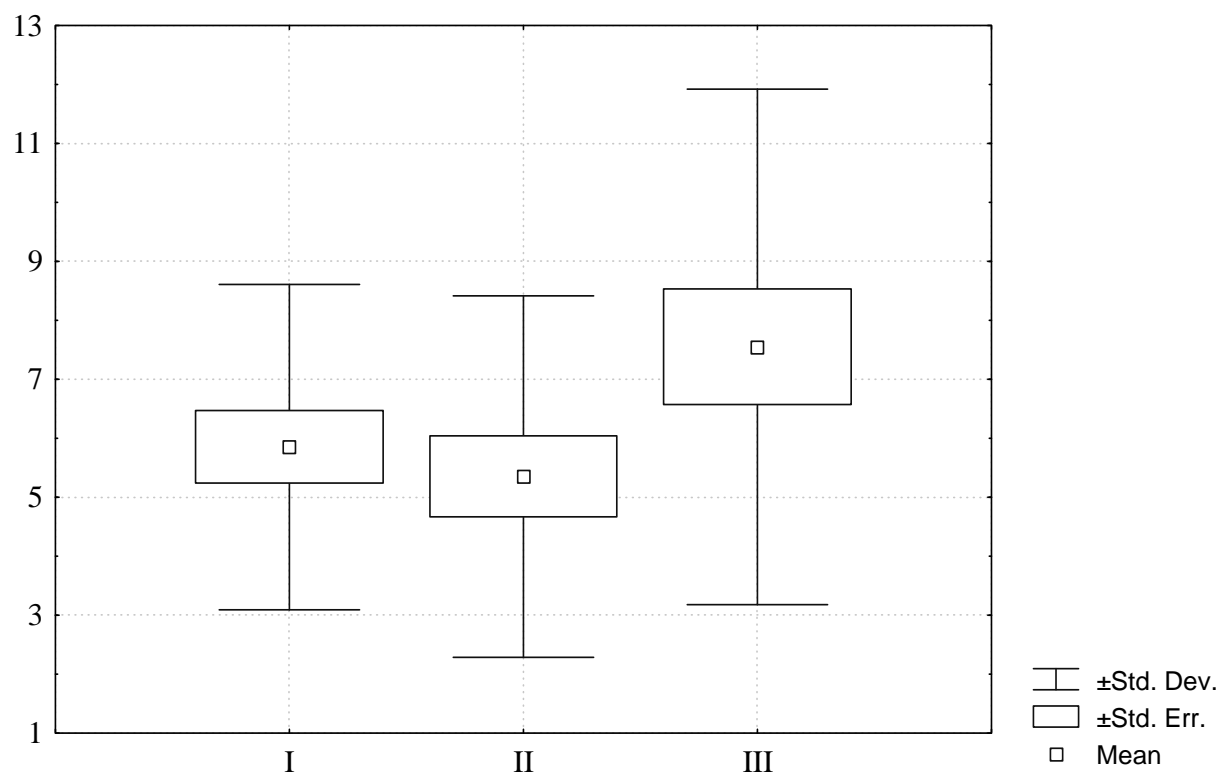

Fig. 2. Values of DMFT - index after treatment in subjects of all groups

fluoride dentifrice could indeed be considered an efficient preventive method to enhance enamel resistance against the cariogenic challenges during orthodontic therapy (Lovrov et al., 2007).

In orthodontics caries usually occurs on smooth surfaces, affecting 2 to $96 \%$ of all orthodontic patients (Richter et al., 2011). Increase in caries risk during such treatment is due to several factors; lesions are difficult to locate, lowering of resting $\mathrm{pH}$, increased volume of dental plaque and rapid shift in bacterial flora (Srivastava et al., 2013). Maxillary lateral incisors, maxillary canines and mandibular premolars are the most commonly affected teeth (Boersma et al., 2005). However, any tooth may be involved and often a number of anterior teeth show demineralization. Different brushing techniques have been advised by orthodontists to maintain oral hygiene, whereas soft brushes advised by some orthodontists lead to plaque deposition around orthodontic appliances.

Some authors suggested that orthodontic treatment with a fixed appliance may be compromised with an increased incidence of caries (Al Mulla et al., 2009). Vander Veen et al. (2010) in the presented study showed that orthodontic treatment with a fixed appliance increased the caries risk. The change in DMFT-index counts during orthodontic treatment was detected in the control group who didn't include preventive treatment. After the treatment with fixed orthodontic appliances, the statistical significance value of the DMFT-index in the control group was increased. This indicates that the acid $\mathrm{pH}$ persists in the oral medium for a longer time, so that it cannot be accepted as an indication of increased caries activity in the subjects.

The increase in carious lesions during treatment with fixed orthodontic appliances has been confirmed by other investigators as well. Pancherz and Mulich (1997), examined 108 patients for carious lesions before and after orthodontic treatment. They detected new or increased number of carious lesions in $29.4 \%$ of the teeth examined. This study reveals the importance of oral hygiene maintenance by the patient and the dentist. The increased frequency of carious lesions in 12-month group shows that after orthodontic treatment, patient's motivation towards maintenance of oral hygiene is diminished. Both groups of our patients used fluoride toothpastes and mouthwashes during the entire treatment as instructed without any difficulty. This recommendation was given for promotion of remineralization and increase of enamel resistance during treatment. The results of this study can be compared to similar studies in which clinical effects of fixed appliances were investigated not only during fixed treatment but also after removal of the bands and brackets (Derks, 2007).

The most important prophylactic measure to prevent the occurrence of caries in orthodontic patients is implementing a good oral hygiene regimen. Good oral hygiene is thus more important in orthodontic patients treated with fixed appliances than in non-treated individuals. Mechanical plaque control by proper tooth brushing is of paramount importance. A modification of the standard toothbrush, use of solutions, and flossing can help patients in attaining good oral hygiene. Use of a power tooth brush or daily water irrigation in combination with manual tooth brushing may be a more effective method in reducing plaque accumulation than manual tooth brushing alone (Harvey and Powell, 1981). Zabokova et al. (2013), in her study concluded that 
improvement of oral hygiene was detected in the group where preventive treatment with Fluorogal was implemented revealing a statistically significant difference between medium values of the simplified oral hygiene index (OHI-S) before and after orthodontic treatment, which was not the case with control group. This finding might be a result of the way of maintenance of oral hygiene (adequate and not adequate oral hygiene). The subjects treated with dental cream (GC Tooth Mousse) had significantly decreased oral hygiene index at the end of orthodontic treatment (1.49) in comparison with the beginning of the treatment, where the average monthly value of the index of oral hygiene was 1.55 . Besides oral hygiene at home, professional prophylactic cleaning is designed to reduce the bacterial load, enhance the efficacy of brushing and facilitate cleaning by the patient. Professional tooth cleaning two or three times a year maintains a healthy mouth and reduces the risk and number of teeth with caries. It allows proper cleaning of the areas that are hard for the patient to brush. The coronal surfaces can be polished using fluoridated pastes of progressively finer particle size, and elastomer polishing cups or brushes, to impede the mechanical retention of bacteria.

\section{Conclusion}

The results of this study show that DMFT-index increased in a group of dental patients undergoing orthodontic therapy with fixed appliances.

The patients must follow good instructions, motivation, and control of oral hygiene during treatment.

\section{References}

Al Mulla, A.H., Kharsa, S.A., Kjellberg, H., Birkhed, D., 2009. Caries risk profiles in orthodontic patients at followupusing Cariogram. Angle Orthod. 79, 323-330. Available at: https://doi.org/10.2319/012708-47.1.

Ali, B.F., Faezeh, E., Imaneh, A., 2011. Association between orthodontic treatment need and caries experience. Acta Odontol. Scand. 69, 2-11. Available at: https://doi.org/10.3109/00016357.2010.516732.

Amy, E.R., Airton, O.A., Mathilde, C.P., Woosung, S., 2011. Incidence of caries lesions among patients treated with comprehensive orthodontics. Am. J. Orthod. Dentofac. Orthop. 139, 657-664. Available at: https://doi.org/10.1016/j.ajodo.2009.06.037.

Anas, H., Mullaa, A.L., Kharsab Saad, A., Kjellbergc, H., Birkhedd, D., 2009. Caries risk profiles in orthodontic patients at follow-up using cariogram. Angle Orthod. 79(2), 323. Available at: https://doi.org/10.2319/012708-47.1.
Boersma, J.G., van der Veen, M.H., Lagerweij, M.D., Bokhout, B., Prahl-Andersen, B., 2005. Caries prevalence measured with QLF after treatment with fixed orthodontic appliances: influencing factors. Caries Res. 39(1), 41-47. Available at: https://doi.org/10.1159/000081655.

Derks, A., Kuijpers-Jagtman, A.M., Frencken, J.E., Van't Hof, M.A., Katsaros, C., 2007. Caries preventive measures used in orthodontic practices: an evidence-based decision? Am. J. Orthod. Dentofac. Orthop. 132, 165-170. Available at: https://doi.org/10.1016/j.ajodo.2005.10.028.

Harvey, W.J., Powell, K.R., 1981. Care of dental enamel for the orthodontic patient. Aust. Orthod. J. 7, 70-76.

Lovrov, S., Hertrich, K., Hirschfelder, U., 2007. Enamel demineralization during fixed orthodontic treatmente incidence and correlation to various oral hygiene parameters. J. Orofac. Orthop. 68, 353-363. Available at: https://doi.org/10.1007/s00056-007-0714-1.

Mattousch, T.J., vander Veen, M.H., Zentner, A., 2007. Caries lesions after orthodontic treatment followed by quantitative light-induced fluorescence: a 2-year follow up. Eur. J. Orthod. 29, 294-298. Available at: https://doi.org/10.1093/ejo/cjm008.

Pancherz, H., Mühlich, D.P., 1997. Entwicklung von Karies bei kieferorthopädischer Behandlung mit festsitzenden Apparaturen - Ein Vergleich von Zähnen mit und ohne Karies vorschädigungen. Kieferorthop 11, 139-144.

Richter, A.E., Arruda, A.O., Peters, M.C., Sohn, W., 2011. Incidence of caries lesions among patients treated with comprehensive orthodontics. Am. J. Orthod. Dentofac. Orthop. 139(5), 657-664. Available at: https://doi.org/10.1016/j.ajodo.2009.06.037.

Roberson T.M., 2006. Cariology: The lesion, etiology, prevention and control. Sturdevant's Art \& science of operative dentistry, fifth ed. Mosby, Elsevier.

Srivastava, K., Tikku, T., Khanna, R., Sachan, K., 2013. Risk factors and management of white spot lesions in orthodontics. J. Orthod. Sci. 2(2), 43-49. Available at: https://doi.org/10.4103/2278-0203.115081.

Stahl, F., Grabowski, R., 2004. Malocclusion and caries prevalence: is there a connection in the primary and mixed dentitions? Clin. Oral Investig. 8, 86-90. Available at: https://doi.org/10.1007/s00784-003-0244-1.

Sukhia, H.R., Ayub, M.A., Gandhi, D., 2006. Enamel decalcification in orthodontic patients; prevalence and oral distribution-across sectional study. Pak. Oral Dental J. 281, 93-97.

Vander Veen, M.H., Attin, R., Schwestka-Polly, R., Wiechmann, D., 2010. Caries outcomes after orthodontic treatment with fixed appliances: do lingual brackets make a difference? Eur. J. Oral. Sci. 118, 298-303. Available at: https://doi.org/10.1111/j.1600-0722.2010.00733.

World Health Organization, 1997. Oral Health Surveys. Basic Methods.

Zabokova-Bilbilova, E., Sotirovska-Ivkovska, A., Stefanovska, E., 2013. The Importance of Proper Oral Hygiene in Patients Undergoing Treatment with Fixed Orthodontic Appliances. Balk. J. Stom. 17(3), 138-143. Available at: https://doi.org/10.2478/prilozi-2014-0021. 


\title{
Резиме
}

\section{Влијанието на ортодонтскиот третман со фиксни апарати на КЕП-индексот}

\author{
Ефка Жабокова Билбилова ${ }^{1}$, Емилија Стефановска ${ }^{2}$, Анета Мијоска ${ }^{3}$, \\ Олга Кокочева Ивановска ${ }^{1}$
}

\author{
${ }^{1}$ Клиника за детска и превентивна стоматологија, Стоматолошки факултет, \\ Универзитет „Св. Кирил и Методиј”, Мајка Тереза, 1000 Скопје, Северна Македонија \\ ${ }^{2}$ Клиника за болести на уста и пародонт, Стоматолошки факултет, \\ Универзитет „Св. Кирил и Методиј”, Мајка Тереза, 1000 Скопје, Северна Македонија \\ ${ }^{3}$ Клиника за протетика, Стоматолошки факултет, \\ Универзитет „Св. Кирил и Методиј”, Мајка Тереза, 1000 Скопје, Северна Македонија
}

Клучни зборови: кариозни лезии, фиксен ортодонтски апарат

Целта на студијата беше да се испитаат промените во денталниот статус кај пациенти кои се случиле во тек на фиксноортодонтски третман.

Вкупно 60 пациенти со дијагностицирана малкоклузија беа вклучени во испитувањето. Испитаниците беа поделени во 3 групи (по 20 испитаници во секоја група). Првата група беше третирана со дентален крем GC Tooth Mousse, а втората група co Fluorogal - раствор со мала концентрација на флуор (0,05\% F). Контролната група ја сочинуваа 20 испитаници. Сите испитаници добија прецизни упатства за орална хигиена и диететски режим на исхрана пред да се постави фиксниот ортодонтски апарат и при секоја контрола. Во нашата студија, регистриран е клинички статус на оралното здравје (КЕП-индексот), пред почетокот и по завршување на ортодонтскиот третман.

Кај испитаниците третирани со дентален крем (GC Tooth Mousse) по завршувањето на ортодонтскиот третман се забележува минимално статистички несигнификантно зголемување на КЕП-индексот 5,85, во споредба пред почетокот на третманот, каде вредноста на индексот беше 5,25. Статистички значајната разлика помеѓу средните вредности на КЕП-индексот пред и по ортодонтскиот третман е забележана кај контролната група на испитаници.

Резултатите од оваа студија покажуваат дека вредноста на КЕП-индексот се зголемуваат кај испитаниците кои подлежат на ортодонтска терапија со фиксни апарати. За време на третманот пациентите треба ги следат упатствата, да се мотивираат и да прават редовна контрола на орална хигиена. 